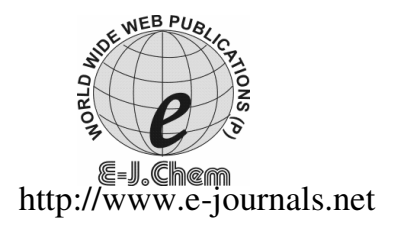

\title{
Recovery of $\mathrm{Al}$ and $\mathrm{Na}$ Values from Red Mud by $\mathrm{BaO}-\mathrm{Na}_{2} \mathrm{CO}_{3}$ Sinter Process
}

\author{
S.N.MEHER ${ }^{*}$, A.K.ROUT and B.K.PADHI ${ }^{\S}$ \\ Department of Chemistry, Kiit University, Bhubaneswar \\ Orissa-751024, India \\ ${ }^{\S}$ National Aluminium Company Limited, R \& D Department \\ Dist-Koraput, Orissa-763008, India \\ shibnarayanmeher@gmail.com
}

Received 26 September 2010; Accepted 27 November 2010

\begin{abstract}
The red mud $\mathrm{BaO}-\mathrm{Na}_{2} \mathrm{CO}_{3}$ sinter process can be used in combination with the Bayer process to recover sodium and aluminium from the red mud waste and direct it back to the process stream. This is facilitated by the high temperature reaction of $\mathrm{BaO}-\mathrm{Na}_{2} \mathrm{CO}_{3}$ and De-silication product (Sodalite) (DSP) in the red mud to produce an insoluble di-barium silicate, barium titanate, barium ferrite and a soluble sodium aluminate. A variation of the red mud $\mathrm{BaO}-\mathrm{Na}_{2} \mathrm{CO}_{3}$ sintering process using half the barium oxide of existing methods has been investigated. The barium to silicon ratio was reduced from 2 to 1 producing a sodium barium silicate $\left(\mathrm{Na}_{2} \mathrm{BaSiO}_{4}\right)$ rather than the di-barium silicate $\left(\mathrm{Ba}_{2} \mathrm{SiO}_{4}\right)$ insoluble phase produced in the existing $\mathrm{BaO}-\mathrm{Na}_{2} \mathrm{CO}_{3}$ sinter method. Synthetic $\mathrm{BaO}-\mathrm{Na}_{2} \mathrm{CO}_{3}$ sinter products were investigated to understand the phases produced during sintering at varying temperatures and the chemistry of extraction. The target phases and morphological behaviors of sinter products were seen in XRD and SEM and the highest extractions were produced from a sinter temperature of $1000{ }^{\circ} \mathrm{C}$ for $4 \mathrm{~h}$. A twostage $\left(105{ }^{\circ} \mathrm{C} / 60 \mathrm{~min}, 105{ }^{\circ} \mathrm{C} / 240 \mathrm{~min}\right)$ water or caustic leaching process was found to be most effective for extraction. Sodium and aluminium extractions were 99\% and $99.5 \%$ respectively. The experimental method devised was then used to treat red mud and the target phases were produced. An extraction of sodium and aluminium of $94 \%$ and $87 \%$ respectively was achieved. Silicon extractions were below $2 \%$. Production benefits include sodium hydroxide savings, liquor burning, increased aluminium extraction and reduced cost of waste handling.
\end{abstract}

Keywords: Red mud, Sodium, Aluminium, Sintering and Extraction

\section{Introduction}

Methods of aluminium and sodium recovery from red mud have been around for many years due to the requirement of some refineries to process very high silica bauxites. The most common 
method to process red mud is the "BaO- $\mathrm{Na}_{2} \mathrm{CO}_{3}$ sinter process". The process ${ }^{1}$ involves adding $\mathrm{BaO}-\mathrm{Na}_{2} \mathrm{CO}_{3}$ to the red mud and sintering at temperatures of $900-1100{ }^{\circ} \mathrm{C}$. The silica in the red mud reacts with barium to form the relatively inert dibarium silicate (eq.1). The sodium, which is in the red mud or added via soda ash or sodium carbonate, reacts with the alumina and forms the soluble sodium aluminate (eq.2) ${ }^{2}$. The $\mathrm{Fe}_{2} \mathrm{O}_{3}$ which is in the red mud reacts with sodium carbonate forms sodium ferrite (eq. 3). The $\mathrm{TiO}_{2}$ which is in the red mud reacts with sodium carbonate forms sodium titanate (eq.4). The Titanium dioxide of red mud reacts with $\mathrm{Ba}(\mathrm{OH})_{2}$ or $\mathrm{BaO}$ forms barium titanate (eq.5 $)^{3-6}$. The Sodium Ferrite reacts with $\mathrm{BaO}$ forms barium ferrite (eq.6).

$$
\begin{aligned}
\mathrm{SiO}_{2}+2 \mathrm{BaO} & \rightarrow \mathrm{Ba}_{2} \mathrm{SiO}_{4} \\
\mathrm{Al}_{2} \mathrm{O}_{3}+\mathrm{Na}_{2} \mathrm{CO}_{3} & \rightarrow 2 \mathrm{NaAlO}_{2}+\mathrm{CO}_{2} \\
\mathrm{Fe}_{2} \mathrm{O}_{3}+\mathrm{Na}_{2} \mathrm{CO}_{3} & \rightarrow 2 \mathrm{NaFeO}_{2}+\mathrm{CO}_{2} \\
\mathrm{TiO}_{2}+\mathrm{BaO} & \rightarrow \mathrm{Na}_{2} \mathrm{TiO}_{3}+\mathrm{CO}_{2} \\
\mathrm{TiO}_{2}+\mathrm{Ba}(\mathrm{OH})_{2} & \rightarrow \mathrm{BaTiO}_{3}+\mathrm{H}_{2} \mathrm{O} \\
2 \mathrm{NaFeO}_{2}+2 \mathrm{BaO} & \rightarrow \mathrm{Ba}_{2} \mathrm{Fe}_{2} \mathrm{O}+\mathrm{Na}_{2} \mathrm{O}
\end{aligned}
$$

The product is then leached in an alkaline solution or water and the sodium aluminate solution is directed to the precipitation stage of the Bayer process.

$$
\begin{gathered}
\mathrm{NaAlO}_{2}(\mathrm{~s})+\mathrm{Ba}_{2} \mathrm{SiO}_{4}(\mathrm{~s})+2 \mathrm{NaFeO}_{2}(\mathrm{~s})+\mathrm{BaTiO}_{3}(\mathrm{~s})+3 \mathrm{H}_{2} \mathrm{O} \rightarrow \\
\mathrm{NaAl}(\mathrm{OH})_{4}(\mathrm{aq})+2 \mathrm{NaOH}(\mathrm{aq})+\mathrm{Ba}_{2} \mathrm{SiO}_{4}(\mathrm{~s})+\mathrm{Fe}_{2} \mathrm{O}_{3}(\mathrm{~s})+\mathrm{BaTiO}_{3}(\mathrm{~s})
\end{gathered}
$$

To produce high aluminium and sodium extractions the decomposition of di-barium silicate must be as low as possible. In practice the amount of silica extracted in the leaching step is too high as the $\mathrm{Ba}_{2} \mathrm{SiO}_{4}$ is not sufficiently stable under the leaching conditions $^{7}$ and silica extractions of around $15-20 \%{ }^{8}$ occur during leaching, tying up sodium and aluminium with the formation of $\mathrm{Ba}_{3} \mathrm{Al}_{2}(\mathrm{OH})_{12}$, Hydro garnet and DSP. The opportunity exists for a process to treat red mud to separate aluminium and sodium from silica, producing an adequately stable insoluble phase for leaching and therefore yielding greater extractions.

An alternative method of $\mathrm{BaO}-\mathrm{Na}_{2} \mathrm{CO}_{3}$ sinter has been presented in this paper to produce a $\mathrm{Ba}: \mathrm{Si}$ ratio of one in the sinter product. The potential benefits are to halve raw material costs and to give a more stable insoluble phase. Also the extra sodium needed could be provided by spent liquor creating the potential for organics removal through liquor burning in the sinter step. However, thermodynamic calculations and laboratory tests show that $\mathrm{BaSiO}_{3}$ does not form under sinter conditions. From the present experiments it was thought that the following $\mathrm{BaO}-\mathrm{Na}_{2} \mathrm{CO}_{3}$ sinter reaction was feasible due to the presence of sodalite in the red mud formed by the reaction of kaolin and sodium aluminate liquor.

$$
\begin{gathered}
\mathrm{Na}_{2} \mathrm{O} \cdot \mathrm{Al}_{2} \mathrm{O}_{3} \cdot 2 \mathrm{SiO}_{2} \text { (sodalite) }+2 \mathrm{Ba}(\mathrm{OH})_{2}+4 \mathrm{Na}_{2} \mathrm{CO}_{3} \rightarrow \\
2 \mathrm{Na}_{2} \mathrm{BaSiO}_{4}+2 \mathrm{NaAlO}_{2}+4 \mathrm{CO}_{2}+2 \mathrm{H}_{2} \mathrm{O}
\end{gathered}
$$

A similar lime sinter process is referred to in a paper discussing the integration of coal combustion with lime sinter ${ }^{9}$. Equation (8) shows that soluble sodium aluminate and sodium barium silicate are produced. The sodium associated with sodium barium silicate must also be recovered in the leaching step. The objective of this project was to investigate the use of a $\mathrm{Ba}: \mathrm{Si}$ ratio of one $\mathrm{BaO}-\mathrm{Na}_{2} \mathrm{CO}_{3}$ sinter process for use as a red mud treatment for the recovery of aluminium and sodium and compare this with the current $\mathrm{BaO}-\mathrm{Na}_{2} \mathrm{CO}_{3}$ sinter system of $\mathrm{Ba}: \mathrm{Si}=2$. 


\section{Experimental}

$\mathrm{BaO}-\mathrm{Na}_{2} \mathrm{CO}_{3}$ sinter products with varying chemical compositions were prepared to gain an insight into the thermodynamics and chemistry of the $\mathrm{BaO}-\mathrm{Na}_{2} \mathrm{CO}_{3}$ sinter process. Both the existing $\left(\mathrm{Ba}_{2} \mathrm{SiO}_{4}\right)$ and new $\left(\mathrm{Na}_{2} \mathrm{BaSiO}_{4}\right)$ method of $\mathrm{BaO}-\mathrm{Na}_{2} \mathrm{CO}_{3}$ sinter were tested for comparison in initially synthetic and then red mud $\mathrm{BaO}-\mathrm{Na}_{2} \mathrm{CO}_{3}$ sinter mixtures. Synthetic mixtures were produced using red mud, $\mathrm{BaO}-\mathrm{Na}_{2} \mathrm{CO}_{3}$ call analytical grades were pulverised, pressed into pellets and sintered and phases confirmed by XRD (Figure 1 and 2) and AAS analysis. Synthetic Phases with iron present were then made using $\mathrm{Fe}_{2} \mathrm{O}_{3}$. The red mud $\mathrm{BaO}-$ $\mathrm{Na}_{2} \mathrm{CO}_{3}$ sinter mixtures were produced similarly, adding $\mathrm{BaO}-\mathrm{Na}_{2} \mathrm{CO}_{3}$ to red mud. The temperature of sintering was varied to optimize extraction. Leaching with water or sodium hydroxide solution was undertaken in an autoclave having 2.5 liter capacity at varying times and temperatures, again to optimize extraction.

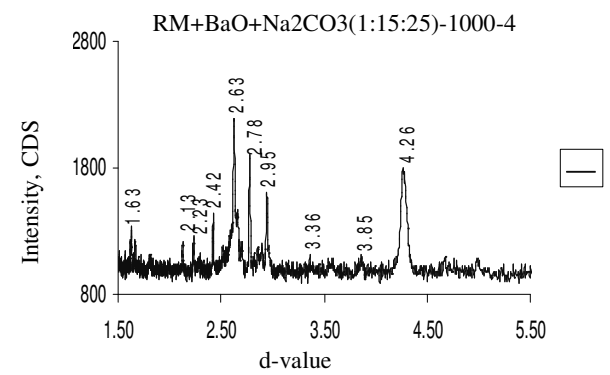

Figure 1. Before leaching

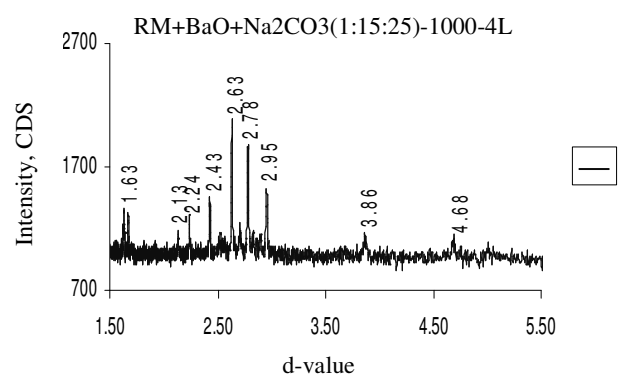

Figure 2. After leaching

\begin{tabular}{cl}
\hline $\mathrm{d}$-Value & \multicolumn{1}{c}{ Phase } \\
\hline 1.63 & Barium Ferrite \\
2.13 & $\mathrm{BaTiO}_{3} /$ Sodium Aluminium oxide \\
2.23 & Sodium Aluminium oxide \\
2.42 & Barium Ferrite \\
2.63 & Sodium Barium Silicate $/ \mathrm{Ba}_{2} \mathrm{Fe}_{2} \mathrm{O}_{5}$ \\
2.78 & Di-Barium Silicate $/ \mathrm{BaFe} \mathrm{O}_{1} 9$ \\
2.95 & Barium Vanadium $\mathrm{Oxide}$ \\
3.15 & Barium Silicate $\left(\mathrm{Ba}_{2} \mathrm{SiO}_{4}\right) / \mathrm{BaMnO}_{3}$ \\
3.36 & Quartz \\
3.85 & Sodium Barium Silicate \\
4.26 & Sodium Barium Silicate \\
\hline
\end{tabular}

\begin{tabular}{cl}
\hline $\mathrm{d}-$ Value & \multicolumn{1}{c}{ Phase } \\
\hline 1.63 & Barium Ferrite \\
2.13 & BaTiO $\mathrm{O}_{3}$ /Sodium Aluminium oxide \\
2.24 & Barium Titanate \\
2.43 & Barium Ferrite \\
2.63 & Sodium Barium Silicate $/ \mathrm{Ba}_{2} \mathrm{Fe}_{2} \mathrm{O}_{5}$ \\
2.78 & Di-Barium Silicate $/ \mathrm{Ba}_{2} \mathrm{Fe}_{2} \mathrm{O}_{5}$ \\
2.95 & Barium Vanadium $\mathrm{Oxide}$ \\
3.86 & Di-Barium Silicate \\
4.68 & Cancrnite \\
\hline
\end{tabular}

Figure 1 \& 2. BaO-soda ash sinter process with highest extraction efficiency $99.50 \%$ at $1000{ }^{\circ} \mathrm{C}$

\section{Results and Discussion}

In the synthetic $\mathrm{BaO}-\mathrm{Na}_{2} \mathrm{CO}_{3}$ sinter stage, calcination at $1000{ }^{\circ} \mathrm{C}$ for $4 \mathrm{~h}$ with red mud $\mathrm{BaO}-\mathrm{Na}_{2} \mathrm{CO}_{3}$ ratio $(1: 0.15: 0.25)$ was found to produce the most stable barium titanate (d value-2.13, 2.24), barium ferrite (d value-1.63, 2.63, 2.43, 2.78), sodium barium silicates ( $d$ value-2.63, 3.85) and dibarium silicates ( $\mathrm{d}$ value-2.78,3.86) which maximized the extraction of aluminium (99.5\%) and sodium (99\%). The formation of small rods agglomerated to each other and whisker like structure indicates the formation of barium ferrite as shown in Figure 3 and Figure 4 at $241 \mathrm{X}$ and $4.69 \mathrm{KX}$ magnification respectively. The formation of large single tetragonal like structure indicates ${ }^{10}$ the formation of barium titanate as shown in Figure 5 . The particles of red mud are agglomerated to each other in sintered red mud as shown in SEM Figure 6. XRD scans (Figure 1 and Figure 2) show the target phases are present as described in Table 1. 


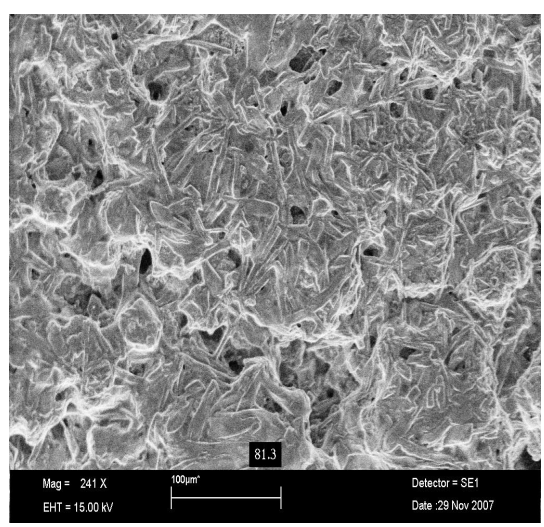

Figure 3. Formation of barium ferrite at $241 \mathrm{X}$

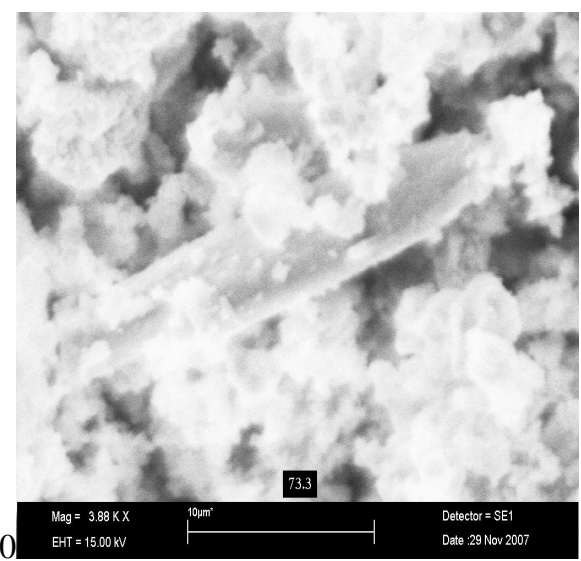

Figure 5. Formation of barium titanate at $3.88 \mathrm{KX}$

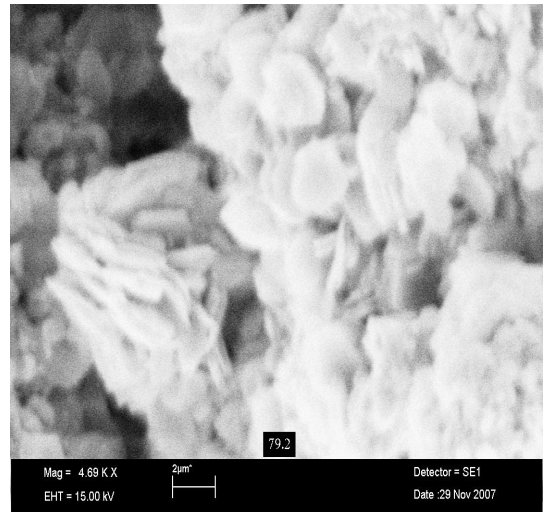

Figure 4. Formation of barium ferrite at $4.69 \mathrm{KX}$

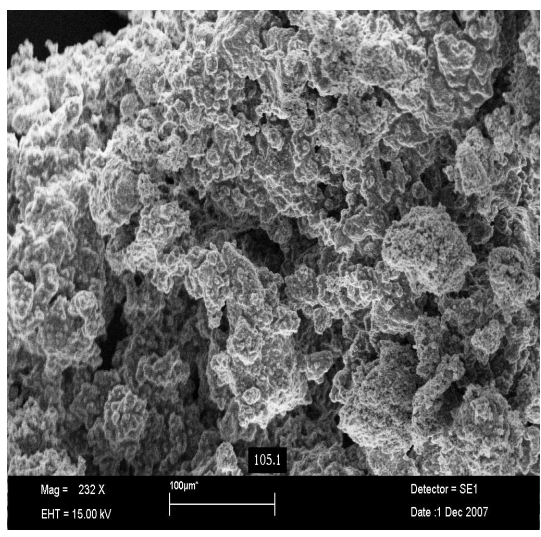

Figure 6. Formation of di-barium silicate and sodium barium silicate at $232 \mathrm{X}$

Table 1. XRD scan of Red Mud-BaO- $\mathrm{Na}_{2} \mathrm{CO}_{3}$ Process with formation of target phases

\begin{tabular}{|c|c|c|c|c|}
\hline \multirow{2}{*}{$\frac{\text { Experiment }}{\text { Target phase }}$} & \multicolumn{2}{|c|}{$\begin{array}{c}\text { Synthetic new } \\
\mathrm{BaO}-\mathrm{Na}_{2} \mathrm{CO}_{3} \text { sinter }\end{array}$} & \multicolumn{2}{|c|}{$\begin{array}{l}\text { Synthetic existing } \\
\mathrm{BaO}-\mathrm{Na}_{2} \mathrm{CO}_{3} \text { sinter }\end{array}$} \\
\hline & $\begin{array}{c}\mathrm{Na}_{2} \mathrm{BaSiO}_{4} \\
+\mathrm{NaAlO}_{2}\end{array}$ & $\begin{array}{c}\mathrm{Na}_{2} \mathrm{BaSiO}_{4} \\
+\mathrm{NaAlO}_{2} \\
+\mathrm{NaFeO}_{2}\end{array}$ & $\begin{array}{c}\mathrm{Ba}_{2} \mathrm{SiO}_{4} \\
+\mathrm{NaAlO}_{2}\end{array}$ & $\begin{array}{l}\mathrm{Ba}_{2} \mathrm{SiO}_{4}+ \\
+\mathrm{NaAlO}_{2} \\
+\mathrm{NaFeO}_{2}\end{array}$ \\
\hline $\begin{array}{c}\text { Phase present in } \\
\text { XRD }\end{array}$ & $\begin{array}{c}\mathrm{Na}_{2} \mathrm{BaSiO}_{4} \\
+\mathrm{NaAlO}_{2}\end{array}$ & $\begin{array}{r}\mathrm{Na}_{2} \mathrm{BaSiO}_{4} \\
+\mathrm{Na}_{2} \mathrm{AlFeO}_{4}\end{array}$ & $\begin{array}{r}\mathrm{Ba}_{2} \mathrm{SiO}_{4} \\
+\mathrm{NaAlO}_{2}\end{array}$ & $\begin{array}{l}\mathrm{Ba}_{2} \mathrm{SiO}_{4}+ \\
\mathrm{Na}_{2} \mathrm{AlFeO}_{4} \\
+\mathrm{Ba}_{2} \mathrm{Fe}_{2} \mathrm{O}_{5}\end{array}$ \\
\hline
\end{tabular}

The existing $\mathrm{BaO}-\mathrm{Na}_{2} \mathrm{CO}_{3}$ sinter product ties some $\mathrm{BaO}$ and $\mathrm{Fe}_{2} \mathrm{O}_{3}$ of red mud to form $\mathrm{Ba}_{2} \mathrm{Fe}_{2} \mathrm{O}_{5}$ ( $\mathrm{d}$ value-1.63, 2.43, 2.63,2.78) which have whisker like structures as shown SEM in Figure 3 and Figure 4 at lower and higher magnification. This meant that extra 
barium was added to ensure the maximum amount of silica was reacted with the barium and not with sodium or aluminium. At $1000{ }^{\circ} \mathrm{C}, \mathrm{Na}_{2} \mathrm{AlFeO}_{4}$ formed in products with iron present in stead of formation of sodium aluminate and sodium ferrite. For the synthetic new $\mathrm{BaO}$ $\mathrm{Na}_{2} \mathrm{CO}_{3}$ sinter system without iron it was found that a two stage water or caustic leach $\left(105^{\circ} \mathrm{C} / 60 \mathrm{~min}, 105^{\circ} \mathrm{C} / 240 \mathrm{~min}\right.$ ) was required to gain maximum $\mathrm{Na}$ and $\mathrm{Al}$ extractions due to the decrease in $\mathrm{Al}$ in solution over time as shown in Figure 7.

This allowed the removal of the majority of the aluminium before the decomposition of the sodium barium silicate and subsequent reaction to form DSP, hydro garnet or $\mathrm{Ba}_{3} \mathrm{Al}_{2}$ $(\mathrm{OH})_{12}$. To ensure leaching conditions were the same for both systems the two-stage process was also employed for the existing lime sinter products. The results of extractions for the sinter products without iron are shown in Figure 8.

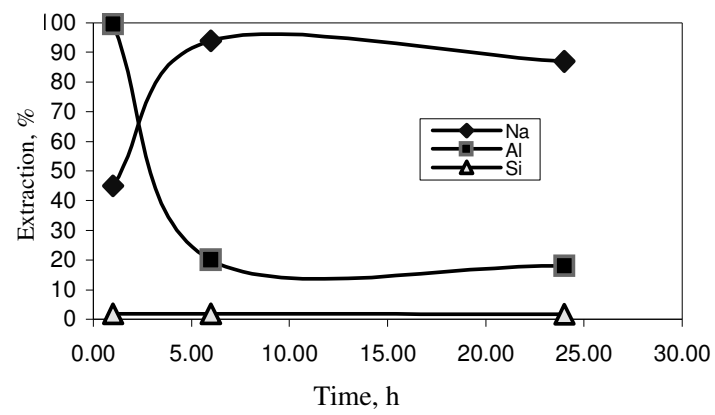

Figure 7. Single stage extraction over time

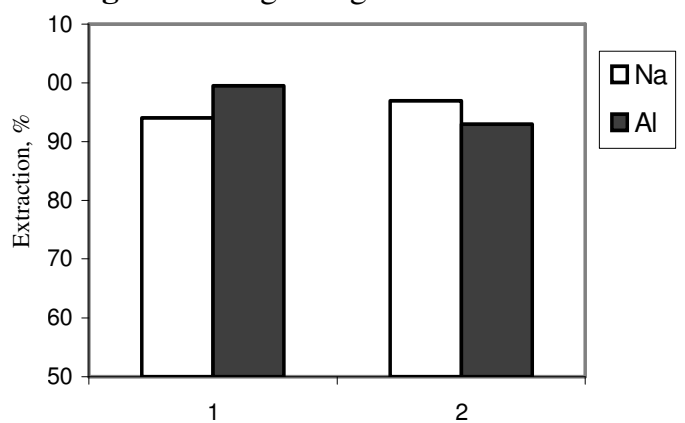

Figure 8. New vs. existing synthetic $\mathrm{BaO}-\mathrm{Na}_{2} \mathrm{CO}_{3}$ sinter without iron

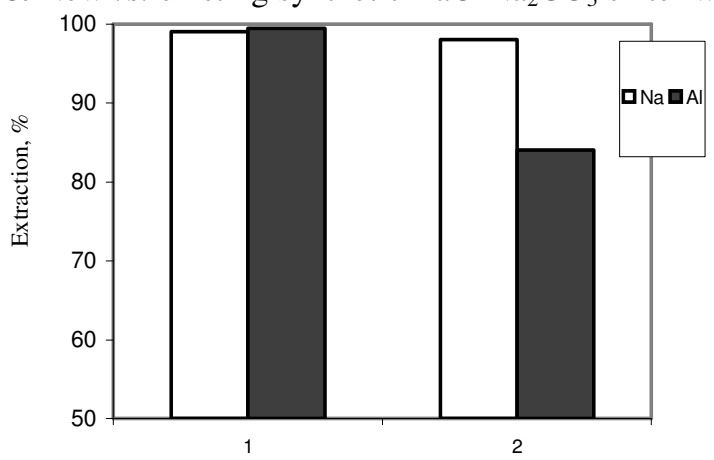

Figure 9. New vs. existing synthetic $\mathrm{BaO}-\mathrm{Na}_{2} \mathrm{CO}_{3}$ sinter 


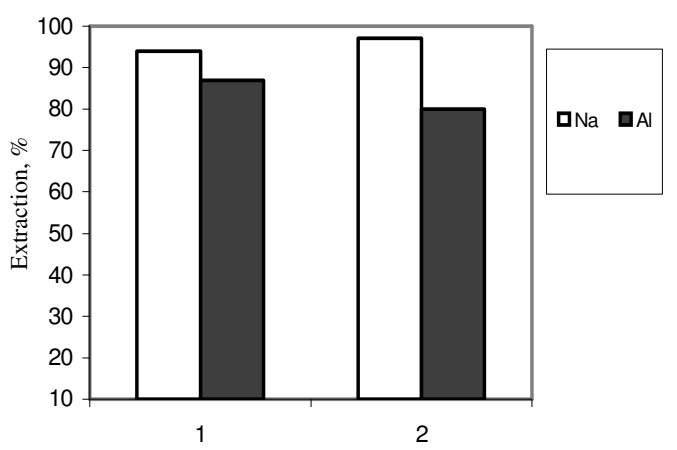

Figure 10. New vs. existing red mud $\mathrm{BaO}-\mathrm{Na}_{2} \mathrm{CO}_{3}$ sinter

When Iron is introduced to the system there are effectively two soluble phases $\left(\mathrm{NaAlO}_{2}+\mathrm{NaFeO}_{2}\right)$ in which the ratio of soluble sodium to soluble aluminium increases. The Figure 9 and Figure 10 show the benefit of the new $\mathrm{BaO}-\mathrm{Na}_{2} \mathrm{CO}_{3}$ sinter method in terms of aluminium extraction. Much of the sodium and all of the aluminium is extracted from the existing $\mathrm{BaO}-\mathrm{Na}_{2} \mathrm{CO}_{3}$ sinter process in the first stage. The second stage merely completes the leaching of sodium. In the new red mud $\mathrm{BaO}-\mathrm{Na}_{2} \mathrm{CO}_{3}$ sinter extraction the resultant solids have a sodium content of $0.06 \%$ compared to the $6.00 \%$ sodium content of the red mud. The aluminium levels have been reduced from $17.8 \%$ to $0.14 \%$. A more stable sodium barium silicate would increase these extractions and could be achieved with the optimization of sinter temperature and leach conditions.

A simulation of the second stage leach, which in the new process aims to recover the sodium from the sodium barium silicate, produced highly concentrated caustic solutions (up to $175 \mathrm{~g} / \mathrm{L}$ ). The extraction was of a synthetic $\mathrm{Na}_{2} \mathrm{BaSiO}_{4}$ (SEM Figure 6) sintered at $1000{ }^{\circ} \mathrm{C}$ and leached with $80 \mathrm{~g} / \mathrm{L}$ caustic solution for $1 \mathrm{~h}$ at $105{ }^{\circ} \mathrm{C}$. The high caustic concentration may be due to the stability of the decomposition products which have a $\mathrm{Ba}: \mathrm{Si}$ of 1 rather than 2. This is a significant result and should be investigated further. When leaching the red mud $\mathrm{BaO}-\mathrm{Na}_{2} \mathrm{CO}_{3}$ sinter products the greater aluminium extraction in the new process was evident however there was less sodium extracted. This may be over come with further optimization of the mole ratios of reactants in the $\mathrm{BaO}-\mathrm{Na}_{2} \mathrm{CO}_{3}$ sinter step. The high silicon extraction that has been reported $^{8}$ was not seen during this present with most experiments producing a silicon extraction of less than $2 \%$ for both the new and existing processes. This may be due to the accuracy of the mole ratios, which can easily be targeted in laboratory conditions compared to in plant conditions where an assay of the red mud to be sintered with $\mathrm{BaO}$ and $\mathrm{Na}_{2} \mathrm{CO}_{3}$ is unlikely to have taken place.

\section{Conclusion}

The new $\mathrm{BaO}-\mathrm{Na}_{2} \mathrm{CO}_{3}$ sinter method with a $\mathrm{Ba}$ : $\mathrm{Si}$ of one proved to be an effective procedure in recovering the sodium and aluminium values from red mud with minimum silicon extraction. The problems with high silica extraction using the existing $\mathrm{BaO}-\mathrm{Na}_{2} \mathrm{CO}_{3}$ sinter method were not evident which may be due to the difference in mole ratio accuracy between laboratory and plant. The advantages of the new $\mathrm{BaO}-\mathrm{Na}_{2} \mathrm{CO}_{3}$ sinter process include a decrease in $\mathrm{NaOH}$ purchases, increased aluminium extraction (99.5\%) and possible organics removal through liquor burning. The potential for producing a concentrated sodium hydroxide solution from the second stage leach is also a major benefit of this system. 
The highest extraction $\left(99.5 \%\right.$ ) was achieved at $1000{ }^{\circ} \mathrm{C}$ in $\mathrm{BaO}-\mathrm{Na}_{2} \mathrm{CO}_{3}$ sinter process is due to formation of dibarium silicate (d-value $=2.78,3.15)$, barium titanate $(\mathrm{d}$-value $=2.13,2.24)$, barium ferrite $(\mathrm{d}$-value $=1.63,2.43,2.63,2.78)$ and sodium aluminate (d-value $=2.13,2.23)$.

\section{References}

1 King W R, High Caustic Mud-Sinter process for high silica whips Bauxite, NonMetallic Materials Research, Kaiser Aluminium and Chemical Corporation, RR 8071, Project 7991-60310, 1980.

2 Leci P and Guidi A, Extractive Metallurgy of Al, 1962, 1, 231-249.

3 Dutta P K, Gallagher P K and Twu J, Chem Mater, 1992, 4(4), 847-851.

4 Pfaff G, J Eur Ceram Soc., 1991, 8(1), 35-39.

$5 \quad$ Xia C T,Shi E W and Zheng W Z, J Inorg Mater., 1995, 10(3), 293.

6 Xia C T, Shi E W, Zhong W Z and Guo J K, J Eur Ceram Soc., 1995, 15(12), 1171.

$7 \quad$ Padilla R and Sohn H Y, Metallurgical Transaction B, 1985, 16(4)B, 707-713

8 Wanchao L, Jiakuan Y and Bo X, IJMP, 2009, 93(3-4), 220-231.

9 Rayzman V L and Filipovich I K, JOM, 1999, 51(8), 16-18.

10 Mingmei W, Junbiao L, Guangguo W, Aihong H, Yuji L, Shochua F and Ruren X, J Am Ceram Soc., 1999, 82(11), 3254-3256. 


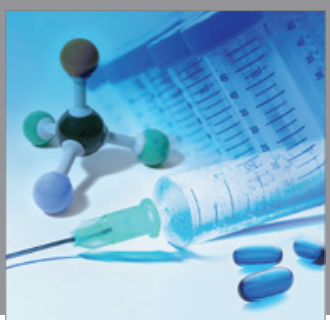

International Journal of

Medicinal Chemistry

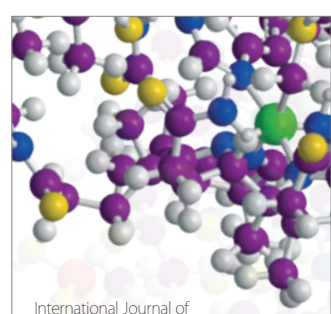

Carbohydrate Chemistry

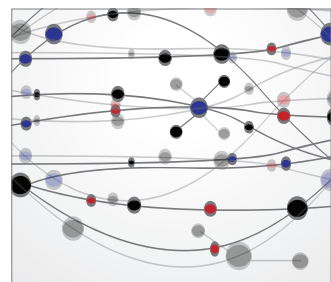

The Scientific World Journal
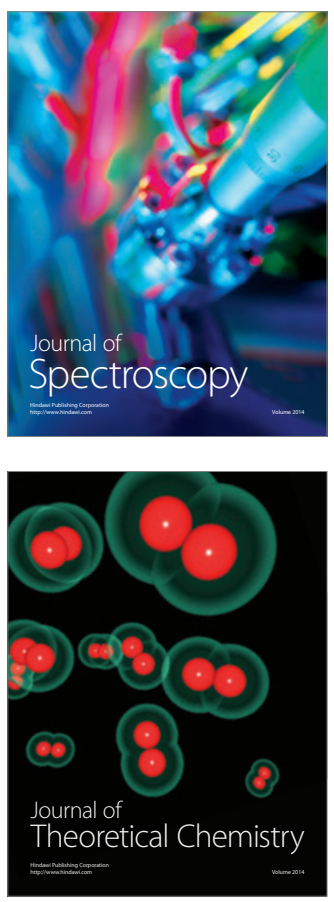
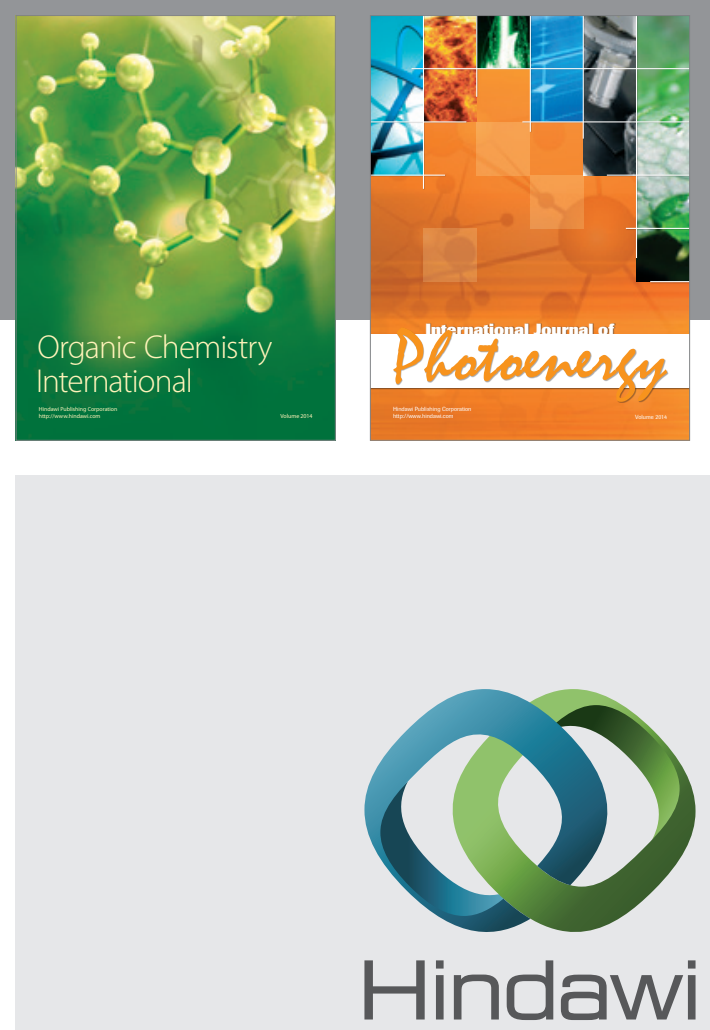

Submit your manuscripts at

http://www.hindawi.com
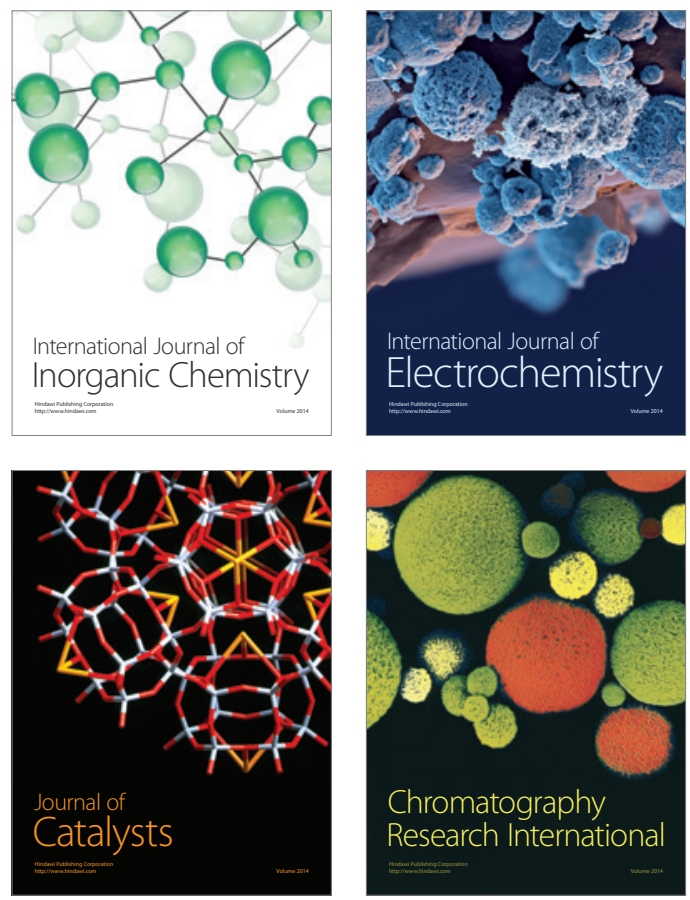
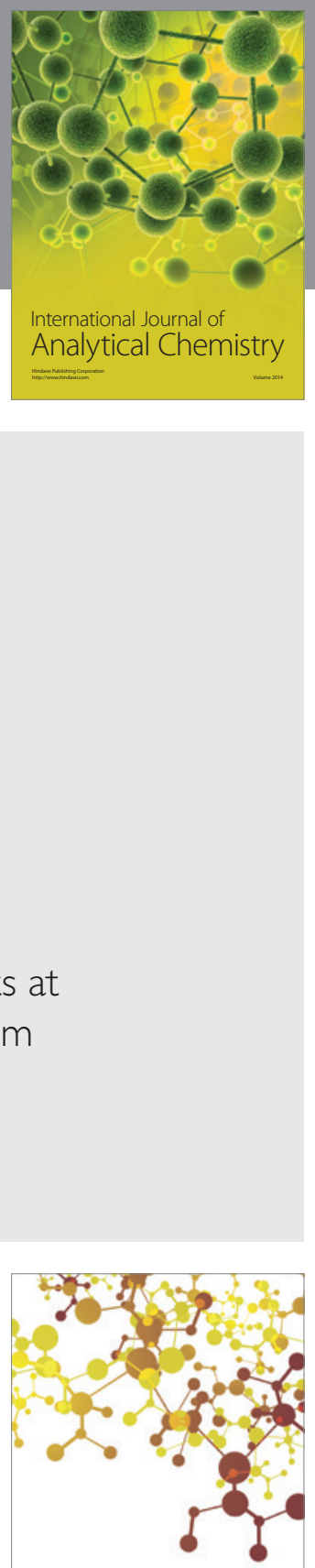

Journal of

Applied Chemistry
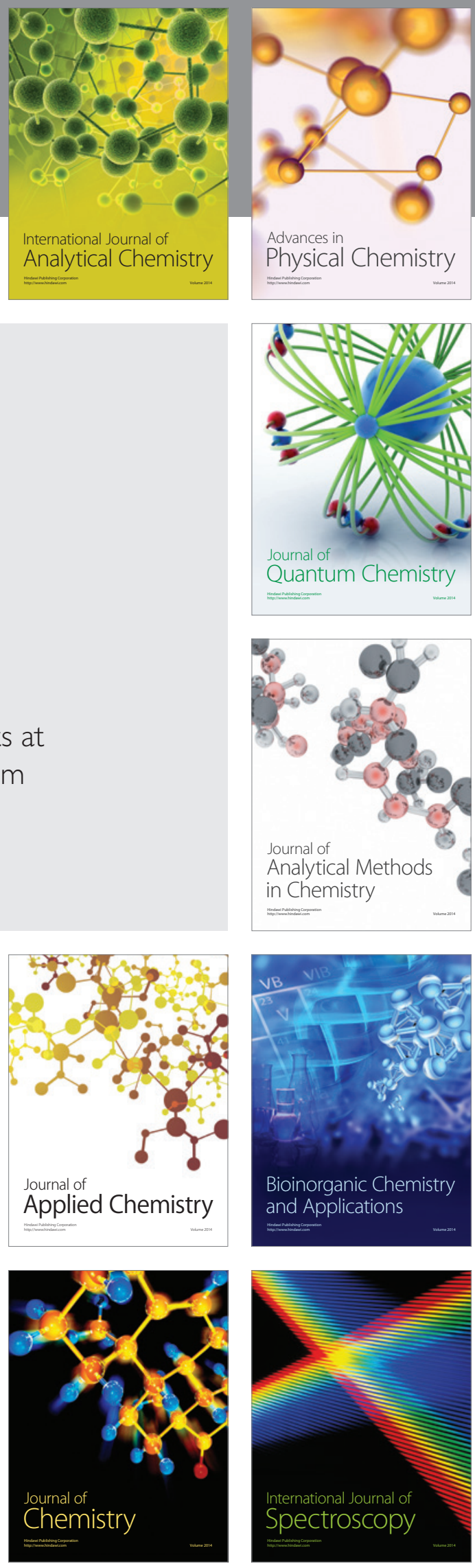